Ryke E, Ngiba T\& H Strydom

\title{
PERSPECTIVES OF ELDERLY BLACKS ON INSTITUTIONAL CARE ${ }^{1}$
}

Elma Ryke, Potchefstroom University for Christian Higher Education, Potchefstroom, Tiny Ngiba, Department of Welfare, Potchefstroom and Herman Strydom, Potchefstroom University for Christian Higher Education, Potchefstroom

\begin{abstract}
This article reports on the perspectives of black elderly persons regarding where they believe persons such as themselves should stay, where they themselves would like to stay, and where their families and children would like them to stay.

Their knowledge of alternative care and their consideration of ever living in an old-age home are also discussed. It was found that the indigenous support system for caring for elderly people in their communities by their children is still practised and preferred by the elderly, but not significantly so by the younger generation. It became clear from the study that old-age homes were still a rather new and largely unacceptable concept to elderly black persons.
\end{abstract}

\section{INTRODUCTION}

The objectives of this article are to report on the findings of an investigation into the perspectives of black elderly persons regarding where they believe persons such as themselves should stay, where they themselves would like to stay, and where their families and children want them to stay. Furthermore, their knowledge of alternative care and whether they would ever consider living in an old-age home are discussed. In the light of these perspectives suggestions will be made for the improvement of service delivery and policy in the field of care for the elderly.

The problem statement and research methodology of the investigation will firstly be discussed. The empirical findings will be reported and certain conclusions and recommendations will conclude the article.

\section{PROBLEM STATEMENT}

Population ageing continues to drive elements of public policy debate in industrialised countries and has also become a factor to be reckoned with in most of the developing world. As a result of the shift in the age distribution, issues regarding support and care services for elderly persons become increasingly important.

The situation in South Africa is no different from that in other countries. According to the 1996 census there were an estimated three million older persons in South Africa, seven out of ten of whom were black (Statistics South Africa, 1998). However, there are unique factors influencing the care of the elderly in South Africa. These factors are mainly cultural and political.

The traditional cultural practice of black people is to keep their elderly persons with them, whilst their white counterparts go to institutions (Moller, 1986:8; Van der Walt, 1990:24).

1 An earlier version of this article was delivered as a paper at the $29^{\text {th }}$ ICSW International Conference on Social Welfare, Poverty, Social Welfare and Social Development: Challenges for the $21^{\text {st }}$ Century, 23-27 October 2000, Cape Town, South Africa. 
Prior to democracy (1994) white elderly persons were spending their last years in old-age homes, while their black counterparts were spending theirs with their family. During the period 1959 to September 1986 the number of subsidised homes for white elderly persons rose from 57 to 405 . It was estimated that the inmate numbers rose from 2800 to approximately 35032 . In the region that was known as the Western Transvaal (pre-1994) there are 30 homes for elderly persons (Department of Health and Welfare, 1990:1). South Africa was one of the Western-influenced countries with the highest rate of white homes for the aged.

However, the non-existence of facilities for elderly black persons compelled black people to utilise their extended family systems and to retain the traditional belief of "not throwing away" their elderly members.

This traditional belief is rooted in the moral obligations of black people having to care for their elderly persons and goes hand in hand with their high regard for values such as friendliness, helpfulness, hospitality, a forgiving nature, patience and brotherliness (Van der Walt, 1990:36). Two elements in particular - people and being available to others - are seen as extremely important; this is explained by the spirit of communalism that is inherent in traditional African culture as opposed to the emphasis on individualism in Western culture (Van der Walt, 1990:37). Duties towards the community are paramount. According to traditional beliefs, all children in the community are children of all adults in the community. It is on the basis of this belief that all elderly persons are supposed to be cared for and respected by all children, irrespective of whether or not they are close relatives. The traditional African belief is "We are, therefore I am". An individual without his or her social relations is unthinkable (Van der Walt, 1994:18).

Strong bonds with the extended family are emphasised in traditional African cultures as opposed to the belief of Westerners in looser bonds with a nuclear and more mobile family. The elderly persons are a source of knowledge as they pass on the values and norms of their societies through generations. Personal communication by means of riddles, proverbs, poetry, stories, drama and songs is seen as a contribution elderly persons make to their families and to the younger generation. Advice from the senior members of the community is regarded as important, hence traditionally every household has elderly persons who are able to give advice in times of need and also to lay down rules on the running of families. Elderly persons are also a potential resource for training and educating the communities on healthy living and child rearing. Most of these elderly persons were (and still are in mostly rural areas) traditional birth attendants and traditional health practitioners. Africans value elderly persons as assets, not for what they can achieve or contribute materially, but because of who they are (Van der Walt, 1994:97, 214).

However, the kinship system that has traditionally provided security in old age has weakened. This happened because of several reasons, e.g. social, economic and political policies of the past, the inequitable distribution of resources, social changes, migration patterns, the growing subculture of violence, and changes in the traditional roles of women and men (Moller, 1986:34; White Paper for Social Welfare, 1997:58). In South Africa it is estimated that at least 50 percent of black South Africans were urban residents at the turn of the century. The changing living circumstances of black elderly persons in South Africa in urban areas therefore raise questions regarding alternative solutions for longer-term care, which has traditionally been assigned to the extended family.

Today many family tasks are being taken over by other societal institutions, while those remaining are often not fulfilled in the way they should be. The closeness and stability of 
earlier family life have declined and even disintegrated in some cases. The family used to be a shock absorber and a stable refuge for all members. Today this shock absorber is failing. Van der Walt (1990:36) states that “...the traditional African culture's responsibility has easily shifted and what was earlier regarded as everybody's responsibility has now easily become nobody's responsibility". Yet in 1993 Strydom (1993:4-5) found that black elderly persons still prefer to stay with their own people as long as possible. He also found that old-age homes were a foreign concept to black communities.

Since the rise of democracy in South Africa in 1994, the policy on care for elderly persons has seen dramatic changes. The government took the initiative to improve the quality of life of all elderly persons. One change was legislation on the admission of all race groups to institutions and for these homes to reflect the broad racial composition of South Africa. The other is the principle of involving elderly persons in the formulation of policies and strategies (FraserMoleketi, 1998:2).

The social welfare policy is also based on the belief that the family is the core of the support system for the elderly (White Paper for Social Welfare, 1997:71). Therefore policy goals, such as cost-effective community-based care programmes to enable elderly persons to stay in the community as long as possible, and support for and training of family members who care for the elderly, are included (South African Council for the Aged, 1998:6). In contrast to previous policy, institutions will only provide frailty care. However, Strydom (2001:104-105) found in an investigation that he undertook in the same community on which this study focuses that housing is a major problem for older persons. The majority of Strydom's respondents also said that they could not function independently in the community. Mokone (1999:136) pleads for more research on the elderly in the process of present policy being translated into programmes in order for these programmes to be appropriate and effective.

While most old-age homes have opened their doors to other race groups, statistics show that the intake of these other race groups has been very low. Ngiba (2000) observed that over the five-year period that facilities were opened to all races, the admission of black elderly persons to old-age homes has been very slow. The figures from the two old-age homes where she has done screening since 1994 reveal that only twenty-one blacks have been admitted. These statistics raised concern and emphasise the need for an investigation to determine the reason(s) for this phenomenon.

\section{RESEARCH METHODOLOGY}

The research design for this study was exploratory (Grinnell \& Williams, 1990:139-140; Rubin \& Babbie, 1997:108-109), seeing that very little is known about the perspectives of black elderly people regarding institutional care. The aim was to explore the perspectives, cultural beliefs and knowledge of alternative care of elderly persons. An interview schedule was utilised in order to conduct interviews. Two Tswana-speaking fieldworkers conducted the interviews. The sample was composed by means of non-probable purposive sampling (Strydom \& De Vos, 1998:198). The sample consisted of 60 elderly black persons (30 men and 30 women) over the age of 65 and living in Ikageng, the black community of Potchefstroom, who were available at the Ikageng pension pay-point. The interviews took place from September to November 2001. 


\section{PERSPECTIVES REGARDING INSTITUTIONAL CARE}

In this section of the article the perspectives of elderly black people are discussed in three sections. The first section covers the issue of where the respondents believe elderly black people should stay, the second where they prefer to stay, and the third covers the preferences of the children and families. Finally, knowledge of alternative care is discussed.

The majority of respondents $(63,34 \%)$ believe that elderly black people belong in the community with their children. Substantially more women (46,67\% to $80,00 \%)$ hold this view. Of the $63,34 \%$ respondents who believed that an old person's place is in the community, however, $6(10,00 \%)$ added a provision to their belief: they believed that old people should stay in the community unless they are ill, unsafe or without care. Those who believe an old person should stay in the community with their children motivated their beliefs by stating that old people are assets to their family and the community, because they help them, take care of them, pay the rent and teach young people. Some stated that things had always been that way and that that was where they belonged. These findings are an indication that the traditional belief in the kinship system was still strong in this sample, especially among the women.

TABLE 1

BELIEFS REGARDING WHERE BLACK ELDERLY PEOPLE SHOULD STAY

\begin{tabular}{|l|l|l|l|}
\hline & \multicolumn{1}{|c|}{ Women } & \multicolumn{1}{c|}{ Men } & \multicolumn{1}{c|}{ Total } \\
\hline In community with children & $24(80,00 \%)$ & $14(46,67 \%)$ & $38(63,34 \%)$ \\
\hline Old-age home & $5(16,67 \%)$ & $5(16,67 \%)$ & $10(16,67 \%)$ \\
\hline Where they prefer & $1(3.33 \%)$ & $10(33,33 \%)$ & $11(18,33 \%)$ \\
\hline Don't know & $0(0 \%)$ & $1(3.33 \%)$ & $1(1,67 \%)$ \\
\hline Total & $30(100 \%)$ & $30(100 \%)$ & $60(100 \%)$ \\
\hline
\end{tabular}

Only $16,67 \%$ of respondents believe elderly black people should stay in an old-age home. These respondents believe that old-age homes provide the necessary care and safety (from abuse by one's own children and also from crime) and a social environment where old people understand each other. If the ten respondents who believe in old-age homes are added to the six that believe elderly people should not stay in the community when they are ill, unsafe or without care, it can be seen that $26,67 \%$ (just over a quarter) will consider alternative care under certain circumstances. This finding could be an indication that the kinship system is failing some elderly people and that, in these circumstances, old-age homes are seen as an option. The sense that old people deserve to be cared for is still strong.

TABLE 2

WHERE ELDERLY BLACK PEOPLE PREFER TO STAY

\begin{tabular}{|l|l|l|l|}
\hline & Women & Men & Total \\
\hline In community with children & $26(86,67 \%)$ & $27(90,00 \%)$ & $53(88,33 \%)$ \\
\hline Old-age home & $4(13,33 \%$ & $3(10,00 \%)$ & $7(11,67 \%)$ \\
\hline Total & $30(100 \%)$ & $30(100 \%)$ & $60(100 \%)$ \\
\hline
\end{tabular}

It is interesting to note that $88,33 \%$ believe that old people should stay where they prefer. It was mostly men who held this belief. Different explanations were given, such as "this is the new South Africa, old-age homes are not for whites only", "as long as they have money", "if 
the home is no good, leave" and "if you don't have children". This "freedom to choose" position could be an indication that a degree of acculturation has taken place in the sense that individualism is preferable to the traditional value of communalism.

The previous question emphasised beliefs. This question emphasises personal preference and the overwhelming majority $(88,33 \%)$ indicated that they preferred staying in the community with their children. However, of these $88,33 \%$, five $(8,33 \%)$ added that, although they prefer staying in the community, they would go to an old-age home if they were faced with illness or disability or if things did not work out at home. Respondents mainly gave two categories of reasons for their preference to stay in the community with their children:

- Children and grandchildren were a major factor (21). The following response represents this category of responses: "I want to guide my grandchildren, because the world has changed a lot".

- A sense of ownership also came out strongly (20). "I want to be there, it is comfortable and peaceful and it is mine" is a response that illustrates this category.

Although only seven $(11,67 \%)$ would like to stay in an old-age home, $13(21,67 \%)$ indicated in response to a question whether they would ever consider living in an old-age home that they would do so. Of those who would consider it, most were men (9 out of the 13 or 69,23\%). Strydom (2001:106) also found this trend of elderly black people not considering old-age homes an option even though housing and independent living were identified as major problems among them. The respondents who would like to stay in an old-age home mentioned that their children were unemployed and could not afford to take care of them; their children took their pension money and did not treat them well. One respondent indicated not having children as a reason. There was also a sense of all needs being provided for in an old-age home.

This finding is a strong indication that elderly black people prefer, and still believe in, traditional customs. Even fewer respondents preferred staying in an old-age home than those who believed old-age homes are where old people should stay. Even the men, contrary to their more liberal belief, preferred staying with their families. Many (both men and women) referred to their responsibility towards children and grandchildren and their children's responsibility towards them as a reason for their preference. One respondent put it as follows: "I raised my children, now it is their turn to help me when I am old. I did not send them away when they were young." Some respondents were still confident that they have something to offer young people. A response that illustrates this point is "Young people learn from old people because they have more knowledge". It seems that old-age homes are only considered an option in the majority of cases where the traditional kinship system has broken down. There is, however, some realisation that illness and frailty could necessitate admission to an old-age home.

The majority of respondents $(61,67 \%)$ said their children preferred that they stay in the community with their children. However, this percentage is much lower than the $88,33 \%$ of old people who preferred staying with their children.

Those who believed their children want them with them $(61,67 \%)$ gave socio-economic, socioemotional and traditional reasons. The men mostly mentioned socio-economic reasons. Responses such as "They need me" (for their home, food, guidance) were given. The women tend to turn to socio-emotional reasons such as "They love and respect me", but the men also made reference to this kind of reason. For instance, one male respondent said: "They like me there, I also love being with them". The men also gave reasons that could be regarded as based 
on traditional views. They said "It is the way it is", "We are a family", "I am their father" and "It is tradition". Two women respondents did not want to live with their children even though their children wanted them there. One said: "I don't want to cause problems for them and their wives". Two respondents said that they did not care what their children wanted, because they wanted their children to take care of them.

TABLE 3

WHERE THEIR CHILDREN PREFER THEM TO STAY

\begin{tabular}{|l|l|l|l|}
\hline & \multicolumn{1}{|c|}{ Women } & \multicolumn{1}{c|}{ Men } & \multicolumn{1}{c|}{ Total } \\
\hline In community with children & $17(56,67 \%)$ & $20(66,67 \%)$ & $37(61,67 \%)$ \\
\hline Don't know & $10(33,33 \%)$ & $5(16,67 \%)$ & $15(25,00 \%)$ \\
\hline Old-age home & $0(0 \%)$ & $1(3,33 \%)$ & $1(1,67 \%)$ \\
\hline Don't care & $1(3,33 \%)$ & $1(3,33 \%)$ & $2(3,33 \%)$ \\
\hline No children & $1(3,33 \%)$ & $2(6,67 \%)$ & $3(5,00 \%)$ \\
\hline On my own & $1(3,33 \%)$ & $1(3,33 \%)$ & $2(3,33 \%)$ \\
\hline Total & $30(100 \%)$ & $30(100 \%)$ & $60(100 \%)$ \\
\hline
\end{tabular}

A quarter of the respondents (25\%) (mostly women) did not know what their children want in this regard. Many of the respondents did not give an explanation, but those who did said that they never discussed the issue with their children. At least one woman said "I am not sure whether they want me there". Another said: "They have their own home". This respondent preferred to go to an old-age home, but it can be deduced that she felt rejected and had no other alternative.

Only three respondents had a more liberal relationship with their children. This is deduced from one woman's statement that her children were satisfied that she stayed on her own, because that was what she wanted. One male said, "I visit them anytime I want" and another said "Where we stay there always are quarrels and in the old-age home they will come to visit and $g o$ ". These responses are an indication of a preference for personal freedom and choice, which does not fit in with the traditional customs of black people.

On the whole it appears that men are more confident than women about their place within the family or elsewhere.

TABLE 4

KNOWLEDGE OF ALTERNATIVE CARE

\begin{tabular}{|l|l|l|l|}
\hline & \multicolumn{1}{|c|}{ Women } & \multicolumn{1}{c|}{ Men } & \multicolumn{1}{c|}{ Total } \\
\hline Old-age homes & $23(82,14 \%)$ & $28(87,50 \%)$ & $51(85,00 \%)$ \\
\hline Service centres & $4(14,29 \%)$ & $1(3,13 \%)$ & $5(8,33 \%)$ \\
\hline Day-care homes & $0(0 \%)$ & $3(9,37 \%)$ & $3(5,00 \%)$ \\
\hline Community-based care & $1(3,57 \%)$ & $0(0 \%)$ & $1(1,67 \%)$ \\
\hline Total & $28(100 \%)$ & $32(100 \%)$ & $60(100 \%)$ \\
\hline
\end{tabular}

\section{KNOWLEDGE OF ALTERNATIVE CARE}

The respondents were asked whether they knew about alternative care for the elderly. More than one response was mentioned. 
The majority of the respondents $(85,00 \%)$ had some knowledge of old-age homes. The other kinds of alternative care services were largely unknown to the respondents. In order to gain insight into their understanding of what these services entail, respondents were asked to describe the service. The following are representative of the responses received:

Old-age homes are:

- $\quad$ places where old people are taken care of (17)

- $\quad$ places were old people can live and die (7)

- $\quad$ places for elderly white people (6)

- $\quad$ places where people pay to live (5)

- $\quad$ homes for abandoned, homeless old people (2)

- $\quad$ places where old people live like children (1)

- $\quad$ places in town for old people (1)

- $\quad$ places for old people with everything they want (1).

Service centres are:

- $\quad$ where people get food, do handwork, come together and perform activities.

Day-care homes are:

- $\quad$ where people go and spend the day and exercise, read and do things

- $\quad$ places where you do not sleep.

Community-based care is:

- $\quad$ where people volunteer to take care of the elderly.

TABLE 5

SOURCES OF INFORMATION REGARDING ALTERNATIVE CARE

\begin{tabular}{|l|l|l|l|}
\hline & \multicolumn{1}{|c|}{ Women $(\mathbf{n}=\mathbf{3 0})$} & \multicolumn{1}{|c|}{ Men $(\mathbf{n}=\mathbf{3 0})$} & \multicolumn{1}{c|}{ Total } \\
\hline Word of mouth & $11(36,67 \%)$ & $15(50,00 \%)$ & $26(43,33 \%)$ \\
\hline Radio & $0(0,00 \%)$ & $15(50,00 \%)$ & $15(25,00 \%)$ \\
\hline Self or somebody I know worked there & $5(16,67 \%)$ & $0(0,00 \%)$ & $5(8,33 \%)$ \\
\hline Just know & $0(0,00 \%)$ & $4(13,33 \%)$ & $4(6,67 \%)$ \\
\hline Community facility & $4(13,33 \%)$ & $0(0,00 \%)$ & $4(6,67 \%)$ \\
\hline Books/newspapers & $0(0,00 \%)$ & $3(10,00 \%)$ & $3(5,00 \%)$ \\
\hline Television & $0(0,00 \%)$ & $1(3,33 \%)$ & $1(1,67 \%)$ \\
\hline Total responses & $20(66,67 \%)$ & $38(126,67 \%)$ & $58(96,67 \%)$ \\
\hline
\end{tabular}

Most respondents gathered their information by word of mouth. It is through their children, family, friends and community members that they become informed. In the case of men, the radio is also an important source of information, but apparently not so with women. The five women who either worked at an old-age home or knew somebody who did all said that they would never consider staying in an old-age home. 


\section{CONCLUSIONS AND RECOMMENDATIONS}

From the literature review it was clear that even though studies had been undertaken on the elderly, not much work had been done on the perspectives of elderly blacks regarding institutional care. Available information also showed that South Africa is one of the countries with a high level of Western influence and the presence of white elderly persons in homes for the aged. Equitable utilisation of old-age homes is still a problem, even though facilities have been open to all races since 1994. It has also become clear that old-age homes are a new and largely unacceptable concept to elderly black people. The indigenous support system of caring for their elderly within families is still practised and preferred by the elderly, but probably not to the same extent by the younger generation.

A definite gender difference emerged regarding the perspectives of the respondents. Men are definitely more confident that their place is with the family and that they are needed there. Men are also more positive about old-age homes than women. Alternative forms of care, old-age homes excluded, are largely unfamiliar to the elderly. The hypothesis that the perspectives of elderly blacks play a role in the under-utilisation of old-age homes by elderly blacks was supported by the investigation reported on in this article. If relevant care is not provided and if people are not familiar with the fact that care is provided, the elderly will suffer.

The investigation indicates a negative perspective on, as well as an unfamiliarity with, old-age homes as a form of care for the elderly. This can explain the low number of admissions of elderly black people to old-age homes. Government departments and old-age homes should take cognisance of these views of elderly black people on institutional care in their recruitment of elderly black persons if they want to increase admissions.

Old-age homes should be marketed in a culturally congruent manner. In this regard social marketing (Weyers, 1999) could be utilised to increase the acceptability of alternative forms of care of old people. In the light of the fact that elderly black people gain most of their information by means of personal communication, social marketing could include riddles, proverbs, poetry, stories, drama and songs as communication media. The radio could also be used to target men and community facilities to reach women.

The traditional beliefs of the elderly, as well as the more modern views of some, should be respected and incorporated into the planning and implementation of services to be rendered to elderly black people. The obvious starting point is to give such people a voice by granting legitimacy to their views and advocating culturally sensitive facilities and services. Gender differences should be taken into consideration. As indicated by the findings of the study reported on in this article, there is a significant difference between the perspectives of elderly black women and men.

The perspectives of the children and grandchildren of elderly black people should also be investigated, as this investigation points towards a possible discrepancy between the perspectives of the elderly and those of their families. This discrepancy could impact seriously on the social welfare policy goal of enabling elderly persons to stay in the community as long as possible. For this goal to be realised, it could be necessary to re-establish the traditional view that old people are an asset to the community and that their contribution is valuable (even to the modern family). Social marketing could also be utilised in this regard. The younger generation, but also the elderly themselves, should be the target of this marketing as it is not only the younger generation who do not value the traditional kinship system, but elderly people themselves seem to be starting to doubt its value. 
The translation of government policy into services should occur in concert with a critical evaluation of the appropriateness and effectiveness of the policies. If the policy goal is to increase admissions of frail elderly black people in old-age homes, the changing perspectives in the black community (old and young) on old-age homes and even possibly changing the nature of old-age homes should be looked into. If government aims to reinforce the indigenous system of black communities caring for their elderly, some effort should go into reinforcing the weakening support systems of families. Policy-making could also be strengthened in terms of both economic and cultural considerations. Policy without commitment has no impact.

Social workers in this field are valuable sources of information regarding the effect of the implementation of these policy goals on the aged as well as on service rendering. Regular feedback on their findings should be provided to the relevant structures. Universities can be contracted to do this research for them.

Finally, the perspectives of elderly black people in other regions should be investigated in order to establish to what degree the findings of this investigation could be generalised to the rest of the elderly black population in South Africa.

\section{REFERENCES}

DEPARTMENT OF HEALTH AND WELFARE 1990. Manual for the care of elderly in old-age homes. Government Printer.

FRASER-MOLEKETI, G. 1998. New measures to protect the elderly. Welfare Update, 4(3):1.

GRINNELL, R.M. \& WILLIAMS, M. 1990. Research in social work: a primer. Itosca: Peacock Publishers.

MOKONE, J.M. 1999. The role played by the family as a support system for the elderly and the challenges of caregiving. Social Work/ Maatskaplike Werk, 35(2):133-137.

MOLLER, V. 1986. Black South African's perceptions of financial security in old age. Pretoria: HSRC.

NGIBA, T. 2000. Social worker responsible for admission screenings of aged persons to oldage homes in Potchefstroom. Personal communication.

RUBIN, A. \& BABBIE, E. 1997. Research methods for social work. London: Brooks Cole Publishing Company.

SOUTH AFRICAN COUNCIL FOR THE AGED 1998. Journal of the South African Council for the Aged. Cape Town.

STATISTICS SOUTH AFRICA 1998. The people of South Africa, population census, 1996. Pretoria: Statistics South Africa.

STRYDOM, H. 1993. Profiel van 'n swart bejaarde te Ikageng. Departement Maatskaplike Werk. Potchefstroomse Universiteit vir Christelike Hoër Onderwys, Potchefstroom.

STRYDOM, H. 2001. Social development of and services for disadvantaged older persons in Potchefstroom. The Social Work Practitioner-Researcher, 13(2):98-117.

STRYDOM, H. \& DE VOS, A.S. 1998. Sampling and sampling methods. In: DE VOS, A.S. (ed) Research at grass roots. A primer for the caring professions. Pretoria: Van Schaik. 
VAN DER WALT, B.J. 1990. Being human - A gift and a duty. University of Potchefstroom: Central Publications Department.

VAN DER WALT, B.J. 1994: The liberating message. University of Potchefstroom: Central Publications Department.

WEYERS, M.L. 1999. The nature and implication of social marketing: a community work perspective. Social Work/ Maatskaplike Werk, 35(2):124-132. 